\title{
PENERAPAN MODEL PICTURE AND PICTUREUNTUK MENINGKATKAN KEAKTIFAN KETERAMPILAN BERBICARA DALAM MATA PELAJARAN BAHASA INDONESIA PADA SISWA KELAS IIIMI AL-MAWASIRPADANG KALUADUL
}

\author{
Islawati \\ Institut Agama Islam Negeri Palopo \\ Jl. Agatis Balandai, Kota Palopo \\ E-mail: islawati181@gmail.com
}

\begin{abstract}
This research reveals the application of picture and picture learning model by determining the subject matter which become the focus of the study, namely the activity on students' speaking skill. Thus, the purpose of this study to determine the ability of students 'speaking skills in the learning process using the media images in class III MI Al-Mawasir Padang Kalua'. The implementation of research using quantitative and qualitative approach. The type of research used is classroom action research (PTK) designed through three cycles. Each cycle lasts for two meetings. Subjects in this study were third grade students MI Al-Mawasir Padang Kalua, which amounted to 18 students consisting of 10 men and 8 women. Data collection techniques conducted in this study, namely interviews, tests, and observations. This research uses qualitative and quantitative data analysis techniques. Qualitative data was analyzed by qualitative descriptive analysis technique, ie categorization, data presentation, and data reduction, while quantitative data was analyzed by using percentage formula. The results of this study indicate that the average value of activity in students' speaking skills increases in each cycle. In the first cycle with a mean score of 68.05, it increases in cycle II with the average value of 71.52, and increasing again in cycle III with the average value of 84.72. Thus, it can be seen that the use of modelpicture and picture can effectively improve the students' speaking skills in the class IIIMI Al-Mawasir Padang Kalua.
\end{abstract}

Keywords: Picture and picture, liveliness, speaking skills

\begin{abstract}
Abstrak
Penelitian ini mengungkapkan penerapan model pembelajaran picture and picture dengan menetapkan pokok masalah yang menjadi fokus kajian, yaitu keaktifan pada keterampilan berbicara siswa. Dengan demikian, tujuan penelitian ini untuk mengetahui kemampuan keterampilan siswa berbicara dalam proses pembelajaran dengan menggunakan media gambar di kelas III MI Al-Mawasir Padang Kalua'. Pelaksanaan penelitian menggunakan pendekatan kuantitatif dan kualitatif. Jenis penelitian yang digunakan, yaitu penelitian tindakan kelas (PTK) yang didesain melalui tiga siklus. Setiap sisklus berlangsung selama dua kali pertemuan. Subjek dalam penelitian ini adalah siswa kelas III MI Al-Mawasir Padang Kalua, yang berjumlah 18 siswa terdiri atas 10 orang laki-laki dan 8 orang perempuan. Teknik pengumpulan data yang dilakukan dalam penelitian ini, yaitu wawancara, tes, dan pengamatan. Penelitian ini menggunakan teknik analisis data secara kualitatif dan kuantitatif. Data kualitatif dianalisis dengan teknik analisis deskriptif kualitatif, yaitu kategoridata, penyajian data, dan reduksi data, sedangkan data kuantitatif dianalisis dengan menggunakan rumus persentase. Hasil penelitian ini menunjukkan bahwa nilai rata-rata keaktifan pada keterampilan berbicara siswa meningkat pada setiap siklusnya. Pada siklus I yang nilai rataratanya 68,05, meningkat pada siklus II yang nilai rata-ratanya 71,52, dan semakin meningkat lagi pada siklus III yang nilai rata-ratanya 84,72. Dengan demikian, dapat diketahui
\end{abstract}




\section{2 | Islawati}

penggunaan modelpicture and picture secara efektif dapat meningkatkan keterampilan berbicara siswa pada kelas IIIMI Al-Mawasir padang Kalua.

Kata Kunci,: Picture and picture, keaktifan, keterampilan berbicara.

\section{PENDAHULUAN}

Pada dunia pendidikan dibutukan pembelajaran yang bermutu. Pembelajaran adalah suatu proses atau kegiatan yang bersifat interaktif dan komonikatif antara pendidik, dengan peserta didik. Sumber belajar dan lingkungan untuk menciptakan suatu kondisi yang memungkinkan terjadinya tindakan belajar peserta didik, baik dikelas maupun diluar kelas, dihadiri guru secara fisik atau tidak, untuk dapat menguasai kompetensi yang telah ditentukan (Zainal Arifin, 2010:10). Pendidikan adalah aktivitas atau proses sosial yang esensialmemungkinkan generasi mudah hidup eksis dalam kompleksitas sosial, modernisasi ekonomi, serta kemajuan ilmu pengetahuan dan teknologi(Sudarwan Denim, 2011:4). Adapu tujuan pembelajaran yaitu memperjelas arah yang ingin dicapai dalam suatu kegiatan belajar, dan mampu memperole hasil yang maksimal dalam melaksanakan proses pembelajaran (Hamzah B. Uno 2011:34). Ada tiga ciri khas yang tekandung dalam sistem pembelajaran, yaitu : 1) Rencana ialah penataan ketenagaan, material, dan prosedur, yang merupakan unsur-unsur sistem pembelajaran, dalam suatu rencana khusus. 2) Kesaling tergantungan, (interdependence), antara unsur-unsur sistem pembelajaran yang serasi dalam suatu keseluruhan. Tiap unsur bersifat esensial, masing-masing memberikan sumbangannya kepada sistem pembelajaran. 3) Tujuan, sistem pembelajaran mempunyai tujuan tertentu yang hendak dicapai(Oemar Hamalik, 2011:66). Sedangkan belajar adalah perubahan tingkah laku yang disebabkan oleh pelatihan dan pengalaman (Hasan Basri, 2015:13).

Pembelajaran yang bermutu, kerjasa antara guru dan siswa. Terutama pada siswa, siwa harus aktif dalam melakukan pembelajaran. Keaktifan siswa sangat diperlukan, karna tampa siswa aktif pembelajaran yang dilakukannya setiap hari akan sia-sia saja. Belajar siswa aktif adalah cara mengajar dengan melibatkan siswa secara optimal dalam intelektual edukatif. Keaktifan belajar siswa merupakan suatu pendekatan mengajar yang menekankan adanya aktivitas siswa secara fisik, mental, intelektual, dan emosional untuk memperoleh hasil belajar yang maksimal, baik rana kongnitif, efektif maupun psikomotorik(Subana dan Sunati, 2004:31). Adapun kektifan belajar secara active menurut mohammad jauhar (2011:156) homby menyatakan aktif yakni terbiasa berbuat segala hal dengan menggunakan segala daya. Pembelajaran yang aktif berarti pembelajaran yang memerlukan keaktifan

PiJIES: Pedagogik Journal of Islamic Elementary School 
semua siswa dan guru secara fisik, mental, emosional, bahkan moral dan spiritual. Dengan melibatkan aspek spiritual, siswa mampu mempertimbangkan hal-hal yang baik dan buruk berdasarkan nilai agama dalam mengikuti proses pembelajaran (Thaha \& Rustan, 2017). Selanjutnya, keaktifan belajar juga berupa kegiatan fisik dan kegiatan psikis. Kegiatan fisik bisa berupa membaca, mendengar, menulis, berlati keterampilanketerampilan, dan sebagainya. Sedangkan kegiatan psikis misalnya menggunakan khazanah pengetahuan yang di miliki dalam memecakan masalah yang di hadapi, membandingkan satu konsep dengan yang lain, menyimpulkan hasil percobaan dan kegiatan psikis yang lain (Rusman dkk, 2013:24). Pembelajaran aktif merupakan pembelajaran yang lebih banyak melibatkan aktivitas siswa dalam mengakses berbagai informasi dan pengetahuan untuk dibahas dalam kajian proses pembelajaran di kelas, sehingga mereka mendapatkan berbagai pengalaman yang dapat meningkatkan pemahaman dan kompetensinya (Rusman, 2011:324).

Adapun pelajaran yang mengharuskan siswa aktif dalam belajar, yaitu pembelajaran Bahasa Indonesia, karena pembelajaran Bahasa Indonesia mengharuskan siswa aktif dalam menulis, membaca terutama dalam keterampilan berbicara. Untuk itu perlu dilakukan upaya pengembangan, baik melalui jalur pendidikan formal maupun nonformal(Zulela, 2013:1). Dalam dunia pendidikan di negara memerlukan sebuah bahasa yang seragam sehingga kelangsungan pendidikan tidak terganggu. Bahasa Indonesia merupakan satu-satunya bahasa yang dapat memenuhi kebutuhan akan bahasa yang seragam dalam pendidikan di Indonesia. Pemakaian Bahasa Indonesia dalam dunia pendidikan tidak hanya terbatas pada bahasa pengantar, tetapi juga bahan-bahan ajar juga memakai Bahasa Indonesia (Nurdjan dan Rustam, 2010:13).

Pengajaran Bahasa Indonesia memiliki 4 aspek keterampilan, salah satunya adalah keterampilan berbicara. Berbicara merupakan salah satu aspek keterampilan berbahasa yang bersifat produktif. MenurutKundharu Saddhono \& Slamet (2014:58)Tarigan menyatakan berbicara adalah kemampuan mengucapkan bunyi artikulasi atau kata-kata untuk mengekspresikan, menyatakan serta menyampaikan pikiran, gagasan dan perasaan. Keterampilan berbicara merupakan salah satu keterampilan berbahasa yang harus diajarkan dan dikuasai peserta didik. Oleh karena itu, keterampilan berbicara bermanfaat untuk meningkatkan komunikasi lisan dengan baik. Keterampilan berbicara juga dapat menunjang keterampilan berbahasa yang lainnya bahkan berperan penting dalam pembelajaran yang lain sehingga pembelajaran dapat berjalan dengan lancar dan kondusif(Septri Wahyuningrum, \& Retno Winarni, Matsuri, 2015: 1). Adapun keterampilan 


\section{4 | Islawati}

berbicara juga dapat di sebut dengan komunikasi, komunikasi berujuk pada suatu proses menyampaikan suatu pertayaan oleh seseorang kepada orang lain. Komunikasi membantu anak menyampaikan pesan dan mengekspresikan emosi tertentu untuk merespon keadaan lingkungan melalui kata-kata (Rustan \& Subhan, 2018).

Cara mengaktifkan keterampilan berbicara siswa, haruslah digunakan suatu metode atau model. Salah satu model yang mampu meningkatkan keaktifan keterampilan berbicara siswa yaitu model picture and picture adalah model suatu model pembelajaran yang menggunakan gambar dan dipasangkan atau diurutkan menjadi urutan logis (Aris Shoimin 2016:122). Adapun pengertian model picture and picture menurutmiftahul huda (2013:236)Suprijono menyatakan bahwa picture and picture merupakan model strategi pembelajaran yang menggunakan gambir sebagai media pembelajaran.Adapun langkah-langkah model picture and picture a) Guru menyampaikan kompetensi yang ingin di capai (3 menit), b)Menyajikan materi sebagai pengantar, c) Guru menunjukkan/memperlihatkan gambargambar kegiatan yang berkaitan dengan materi, d) Guru menunjuk/memanggil siswa secara bergantian memasang/ mengurutkan gambar-gambar menjadi urutan yang logis, e) Guru menanyakan alasan/ dasar pemikiran urutan gambar tersebut, f) Dari alasan/ urutan gambar tersebut guru mulai menanamkan konsep/ materi sesuai dengan kompetensi yang ingin di capai (Agus Suprijono 2014:125-126).

Berdasarkan penjelasan di atas dengan penerapan model picture and picture pemahaman siswa terhadap pembalajaran bahasa Indonesia khususnya keaktifan keterampilan berbicara dapar meningkat, olehnya itu peneliti merancang sebuah penelitian yang berjudul "penerapan model picture and picture untuk meningkatkan keaktifan keterampilan berbicara siswa dalam mata pelajaran bahasa Indonesia pada siswa kelas III MI AlMawasir Padang Kalua".

\section{METODE PENELITIAN}

Penelitian ini merupakan penelitian tindakan kelas yang difokuskan pada aktivitas pembelajaran di dalam kelas. Pendekatan yang digunakan oleh penelitian adalahpendekatan kombinasi. Pendekatan kombinasi adalah metode pendekatan penelitian yang menggabungkan atau menghubungkan metode penelitian kuantitatif dan kualitatif (Sugiono, 2013:19). Peneliti menggunakan model penelitian tindakan kelas yang diterapkan oleh Wina Sanjaya, (2009:49)Kurt Lewin menyatakan Prosedur penelitian 
menggunakan langkah sebagai berikut (1) perencanaan, (2) pelaksanaan, (3) observasi dan (4) refleksi.

Adapun lokasi yang akan dijadikan tempat penelitian yakni di MI AlMawasir padang kalua. Sumber data yang akan digunakan dalam penelitian ini ialah data primer, yaitu data yang akan diambil langsung dari obyek penelitian yaitu; kepalah sekolah MI AL-Mawasir Padang Kalua, guru dan siswa MI AL-Mawasir Padang Kalua. Data yang diperoleh dari guru adalah data yang berupa pernyataan-pernyataan guru tentang keaktifan keterampilan berbicara siswa yang diperoleh melalui kegiatan wawancara, sedangkan data yang diperoleh dari siswa berupa nilai atau angka yang akan menjadi acuan bagi peneliti untuk menilai peningkatan keaktifan keterampilan berbicara pada siswa, Subjek dalam penelitian ini adalah siswa kelas III MI AL-Mawasir Padang Kalua, yang berjumlah 18 siswa yang terdiri dari 10 laki - laki 8 perempuan, dan teknik pengumpulan datanya yaitu 1) wawancara, 2) pengamatan, 3) tes. Penelitian ini menggunakan teknik analisis data secara kualitatif dan kuantitatif.Data kualitatif dianalisis dengan teknik analisis deskriptif kualitatif, yaitu teknik pengolahan data dengan cara mendeskripsikan hasil data kualitatif yang meliputi hasil observasi, catatan lapangan dan hasil wawancara, ada dua cara untuk menstrukturkan hasil penelitian ini yaitu dengan berpegang pada fokus tertentu dalam wawancara, dan wawancra dipandu oleh beberapa pertanyaan(Noeng Muhadjir 2002:142). dan analisis data kuantitatif dianalisis menggunakan rumus persen(Syamsuria, 2011:43).

\section{HASIL DAN PEMBAHASAN HASIL PENELITIAN}

Pada tahapan siklus I guru menjelaskan penggunaan model picture and picture dengan menggunakan media gambar, proses pembelajaran tahap ini guru sudah berusaha mengajar dengan komunikatif dan hanya beberapa siswa terlihat antusias mendengarkan, dan hasil yang ditemukan pada siklus I yaitu: 1) Dalam penerapan model picture and picture hasil yang ditemukan bahwa, siswa belum terlalu paham akan model yang diterapkan dan mereka mengalami kebosanan dan malu untuk tampil di depan kelas, hal ini menunjukkan bahwa partisipasi siswa kurang dalam proses belajar., 2) Setelah diterapkannya model picture and picturehasil keaktifan keterampilan berbicara siswa dalam mata pelajaran bahasa Indonesia kurang meningkat pada saat diberikan tes akhir tindakan siklus I, hasil analisa data tes hasil belajar menunjukan bahwa nilai presentasi keaktifan keterampilan berbicara siswa yaitu 68,05\%, dan belum memenuhi standar KKM 70, karna pada siklus 
I siwa belum paham akan model yang diterapkan dan mereka belum terlau aktif dalam belajar.

Pada tahapan siklus II, sebelum memasuki materi guru memberikan motivasi dan arahan dalam melakukan pembelajaran. Dan guru kembali menjelaskan penggunaan model picture and picture, proses pembelajaran tahap ini guru sudah berusaha mengajar dengan komunikatif dan siswa mulai terlihat antusias mendengarkan. Hasil yang ditemukan pada siklus II yaitu: 1) Dengan penerapan model picture and picture dalam mata pelajara bahasa Indonesia, hasil yang ditemuhkan bahwa siswa mulai mengerti dan paham akan model yang digunakan oleh guru, mereka mulai aktif dalam belajar dan berbicara., 2) Setelah diterapkannya model picture and picture dalam mata pelajaran bahasa Indonesia tingkat keaktifan keterampilan berbicara siswa meningkat, dimana pelaksanaan tes akhir tindakan siklus II, hasil analisa data tes hasil belajar menunjukan nilai presentasi keaktifan keterampilan berbicara siswa yaitu 71,52\%, dan sudah memenuhi standar KKM 70, karna pada siklus II siwa mulai paham dan mengerti apa yang disampaikan oleh guru.

Pada tahan siklus III, sebelum memasuki materi guru kembali memberikan motivasi dan arahan dalam melakukan pembelajaran dan guru kembali menjelaskan penggunaan model picture and picture, proses pembelajaran tahap ini guru sudah berusaha mengajar dengan komunikatif dan hasil yang ditemukan pada siklus III yaitu: 1) Dengan penerapan model picture and picture dalam mata pelajaran bahasa Indonesia siswa sangat antusias mendengarkan, hasil ini disebabkan karna mereka sudah mengerti dan paham akan model yang digunakan oleh guru., 2) setelah diterapkannya model picture and picture tingkat keaktifan keterampilan berbicara siswa dalam mata pelajaran bahasa Indonesia meningkat, dimana pelaksanaan tes akhir tindakan siklus III, hasil analisa data tes hasil belajar menunjukan pada nilai presentasi keaktifan keterampilan berbicara siswa yaitu 84,72\%, karena pada siklus III siswa mulai aktif dalam berbicara dan paham akan model yang digunakan oleh guru.

Peningkatan keaktifan keterampilan berbicara dalam mata pembelajaran Bahasa Indonesia dapat dilihat dari diagram berikut: 


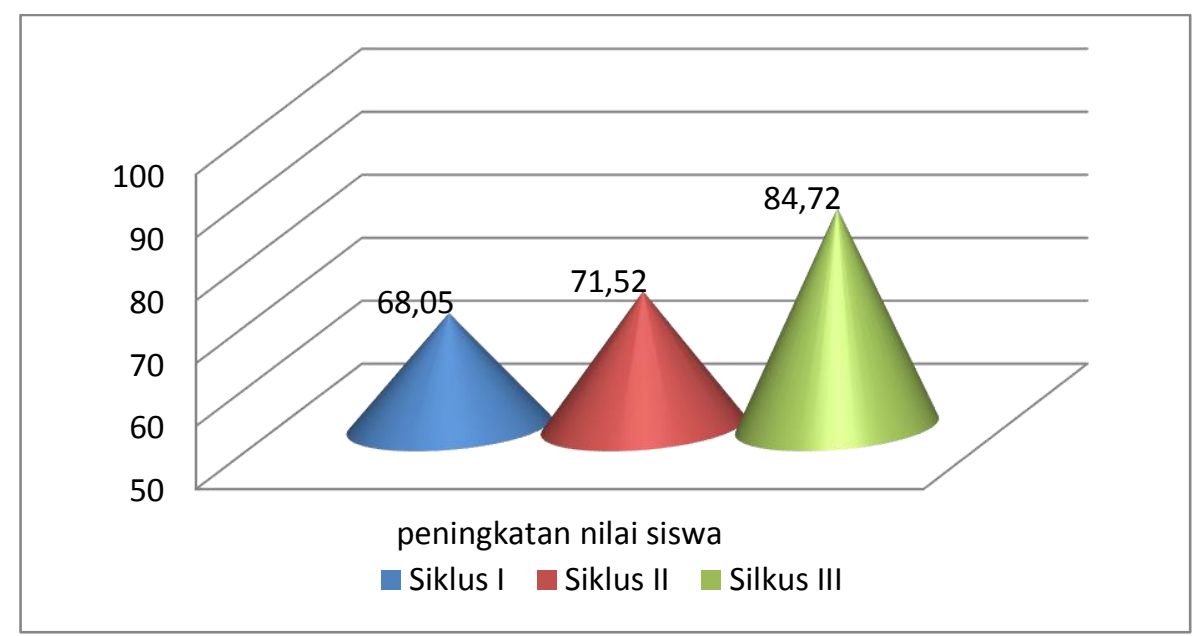

Diagram Peningkatan Nilai Tiap Siklus

Dari diagram tersebut dapat diketahui bahwa nilai keaktifan keterampilan berbicara siswa dalam mata pembelajaran Bahasa Indonesia bertahap meningkat pada tiap siklusnya, dimana nilai siklus I 68,05, siklus II 71,52, dan siklus III 84,72. Dengan demikian dapat diketahui bahwa dengan penggunaan model pembelajaran picture and picture dapat meningkatkan keaktifan belajar siswa pada keterampilan berbicara.

\section{PEMBAHASAN}

Peneliti ini dilakukan sebagai upayah untuk meningkatkan keaktifan keterampilan berbicara dalam mata pelajaran bahasa indonesia pada siswa kelas III MI Al-Mawasir Padang Kalua dengan menggunakan model picture and picture Dalam proses pembelajaran, nilai siswa semakin meningkat pada tiap siklusnya, karena dalam proses belajar peneliti menerapkan model pembelajaran Picture and Picture untuk meningkatkan keaktifan berbicara siswa. Model pembelajaran Picture and Picture ini diulang terus menerus tiap siklusnya. Hal ini sesuai dengan pendapatDimyatiMudjiono (2006:9) Skinner yang mengatakan bahwa belajar adalah suatu perilaku. Pada saat orang belajar, maka responya menjadi lebih baik. sebaliknya, bila ia tidak belajar maka responya menurun. Dalam Hamzah B. Uno(2015:13) Skinner juga menjelaskan bahwa respon yang diberikan oleh siswa tidak sederhana itu, sebab pada dasarnya setiap stimulus yang diberikan berinteraksi satu dengan yang lainnya. Sedangkan respon yang diberikan, dapat menghasilkan konsekuensi yang pada gilirannya akan memengaruhi tingka laku. Oleh karena itu, untuk memahami tingkah laku siswa secara tuntas, kita harus memahami respon itu sendiri dan berbagai konsekuensi yang diakibatkan oleh respon tersebut.

Beberapa hal yang diperoleh dari hasil penelitian pada tiap siklus, yaitu pada tindakan siklus I, ditemukan bahwa sebagian besar siswa masih kurang 


\section{8 | Islawati}

aktif dalam belajar dan berbicar. Mereka masih terkesan malu-malu dan kurang percaya diri. Akan tetapi, pada siklus II siswa mulai aktif dalam mengikuti proses pembelajaran terutama dalam berbicara, dan pada siklus III siswa sangat antusias aktif dalam mengikuti proses pembelajaran, sehingga proses pembelajaran berjalan dengan baik dan memuaskan. Hal ini sesuai apa yang dikemukakan oleh Baharuddin,\&Esa Nur Wahyuni (2012:65)Edward Lee Throndike yang menyatakan bahwa jika sebuah tindakan diikuti oleh perubahan yang memuaskan dalam lingkungan, maka kemungkinan tindakan itu akan diulang kembali akan semakin meningkat. Sebaliknya, jika sebuah tindakan diikuti oleh perubahan yang tidak memuaskan maka tindakan itu mungkin menurun atau tidak dilakukan sama sekali. Adapun yang digunakan peneliti selain menggunakan model picture and picture untuk meningkatkan keaktifan keterampilan berbicara siswa yaitu dengan memberikan motivasi atau berupa kata-kata penyemangat dan hadiah agar siswa aktif dalam proses pembelajaran. Hal ini sejalan dengan teori yang dikemukakan oleh Slameto (2013:17)Maslow yang mengatakan bahwa tingka laku manusia dibangkitkan dan diarahkan oleh kebutuhankebutuhan tertentu.Setelah mengunakan model pembelajaran picture and picture tingkat keaktifan keterampilan berbicara dalam mata pelajaran Bahasa Indonesia pada siswa kelas III MI Al-Mawasir Padang Kalua bertahap meningkat yang dimana nilai dari siklus I 68,05, siklus II 71,52, dan siklus III 84,72 . Hal ini menunjukan bahwa, menggunakan model pembelajaran picture and picture salah satu model pembelajaran yang baik, dan mampu meningkatkan keaktifan berbicara siswa dan proses pembelajaran.

\section{PENUTUP}

Berdasarkan hasil penelitian yang telah dilakukan dapat diketahui bahwa, keaktifan dalam keterampilan berbicara siswa dapat meningkat dengan menggunakan model picture and picture dengan media gambar. Penggunaan gambar sangat efektif dalam meningkatkan keaktifan belajar pada keterampilan berbicara, siswa yang pada awalnya hanya lima orangyang dapat aktif dalam belajar dan empat orang yang mampu berbica menanyakan tentang maksud materi. Setelah menggunakan model pembelajaran picture and picture tingkat keaktifan keterampilan berbicara siswa semakin meningkat pada tiap siklusnya, hal ini menunjukkan bahwa model pembelajaran ini terbukti dapat meningkatkan minat dan motivasi siswa dalam melakukan pembelajaran Bahasa Indonesia pada keterampilan berbicara, serta dapat meningkatkan kreativitas, rasa percaya diri, kecepatan berpikir, dan keterlibatan siswa dalam proses belajar mengajar.

PiJIES: Pedagogik Journal of Islamic Elementary School 
Hasil akhir dari penelitian ini menunjukkan bahwa penerapan model picture and picture dalam proses pembelajaran dapat meningkatkan keaktifan siswa dalam pembelajaran Bahasa Indonesia pada keterampilan berbicara, dengan menggunakan media gambar.Pelaksanaan pembelajaran dengan menggunakan media gambar ternyata memberi pengaruh positif terhadap peningkatan keaktifan belajar dan keterampilan berbicara siswa. Modelpicture and picture merupakan model yang sangat efektif dan layak digunakan sebagai rujukan untuk meningkatkan keaktifan keterampilan berbicara siswa.

\section{DAFTAR PUSTAKA}

Arifin, Zainal. 2014. Evaluasi Pembelajaran, Bandung: PT Remaja Rosdakarya.

Baharuddin,\& Esa Nur Wahyuni. 2012. Teori Belajar dan Pembelajaran, Jogjakarta:Ar-Ruzz Media.

Basri, Hasan. 2015. Paradigma Baru Sistem Pembelajaran, Bandung: Pustaka Setia.

B. Uno, Hamzah. 2011. Perencanaan Pembelajaran, Jakarta: Bumi Aksara. 2015. Teori Motivasi dan Pengukurannya, Jakarta: PT Bumi Aksara.

Danim, Sudarwan. 2011. Pengantar Kependidikan, Bandung: Alfabeta.

Hamalik, Oemar. 2011. Kurikulum Dan Pembelajaran, Jakarta: Bumi Aksara.

Huda, Miftahul. 2013. Model-Model Pengajaran dan Pembelajaran, Yogyakarta: Pustaka Belajar.

Jauhar, Mohammad. 2011. Implementasi PAIKEM dari Behavioristih sampai Konstruktivistih, Jakarta: Prestasi Pustakaraya.

Muhadjir, Noeng. 2002. Metodologi Penelitian Kualitatif,Yogyakarta: Rake Sarasin.

Mudjiono, Dimyati. 2006. Belajar dan Pembelajaran, Jakarta: PT Rineka Cipta. Nurdjan, S., \& Rustan, E. 2010. Kunci Sukses Berbahasa Indonesia, Palopo: Lembaga Penerbitan STAIN.

Rusman. 2011. Model-Model Pembelajaran Mengembangkan Profesionalisme Guru,Jakarta: Rajawali Pers.

Rusman dkk. 2013. Pembelajaran Berbasisi Teknologi Informasi dan Komonikasi, Jakarta: PT Rajagrapindo Bersada.

Rustan, E., \& Subhan. (2018). Komunikasi Verbal Anak Pesisir Usia 7-8 Tahun Pada Transakasi Penjualan Produk Kebudayaan Dengan Turis mancanegara. Jurnal Pendidikan Usia Dini, 12(1), 12-28. https://doi.org/10.21009/JPUD.121 02

Sanjaya, Wina. 2009. Penelitian Tindakan Kelas, Jakarta: Kencana Prenada Media Group. 
Saddhono, Kundharu,\&Slamet. 2014. Pembelajaran Keterampilan Bahasa Indonesia,Yogyakarta: Graham Ilmu.

Suprijono, Agus. 2014. Cooperative Learning Teori dan Aplikasi PAIKEM, Yogyakarta: Pustaka Pelajar.

Subana, \& Sunati. 2004. Strategi Belajar Mengajar Bahasa Indonesia, Bandung: Pustaka Setia.

Shoimin, Aris. 2016. 68 Model Pembelajaran Inovatif dalam Kurikulum2013, Yogyakarta: AR-Ruzz Media.

Sugiono. 2013. Metode Penelitian Kombinasi,Bandung:Alfabeta.

Slameto. 2013. Belajar dan Faktor-faktor yang Mempengaruhi, Jakarta: Rineka Cipta.

Syamsuria. 2011. Peningkatan Hasil Belajar IPA Melalui Model Problem Basic Intrucsion (PBI) Siswa Kelas V SD Inpres 4/82 Biru Kecamatan Taneteriattang Kabupaten Bone Tahun Ajaran.

Thaha, H., \& Rustan, E. (2017). Orientasi Religiusitas dan Efikasi Diri dalam Hubungannya dengan Kebermaknaan Pendidikan Agama Islam pada Mahasiswa IAIN Palopo. Studi Agama Dan Masyarakat, 13(2), 163-179. https://doi.org/10.23971/jsam.v13i2.551

Wahyuningrum, Septri, \& Retno Winarni, Matsuri,"Peningkatan Keterampilan Berbicara dengan Menggunakan Model Pembelajaran Kooperatif Tipe Time Token", (On hine) h:// jurnal.ftkip.uns.ac.id/index.php/pgsdsolo/ article/view/6243. Di akases pada 23 september 2017.

Zulela. 2013. Pembelajaran Bahasa Indonesia,Bandung: PT Remaja Rosdakarya. 